\title{
PENGARUH KEPEMIMPINAN DAN LINGKUNGAN KERJA FISIK TERHADAP MOTIVASI KERJA KARYAWAN \\ CV. SEDULUR PALEMBANG
}

\author{
Oktariansyah *)
}

\begin{abstract}
ABSTRAK
Tujuan Penelitian ini adalah untuk mengetahui pengaruh kepemimpinan dan lingkungan kerja fisik terhadap motivasi kerja karyawan pada CV. Sedulur Palembang. Populasi dalam penelitian ini adalah sebanyak 83 orang pegawai. Dengan tehnik pengambilan sample yang dilakukan secara stratified selanjutnya ditarik secara random dengan menggunakan simple random sampling atau pengambilan secara acak sederhana.

Pengujian Instrumen penelitian ini menggunakan Uji Validitas dan Reliabilitas. Tujuannya adalah agar data yang diambil valid, yakni benar-benar mengukur apa yang hendak diukur. Rancangan penelitian terdiri atas variabel terikat, yaitu motivasi kerja karyawan $(\mathrm{Y})$, variabel bebas, yaitu kepemimpinan $\left(X_{1}\right)$, dan lingkungan kerja fisik $\left(X_{2}\right)$. Untuk teknik analisis dalam pengujian hipotesis yaitu analisis deskriptif, dan analisis inferensial. Untuk uji persyaratan analisis menggunakan uji normalitas, homogenitas, dan linearitas. Uji hipotesisnya dengan melakukan uji signifikansi simultan (uji statistik F), dan uji signifikansi parameter individual (uji statistik t).
\end{abstract}

Kata Kunci : Kepemimpinan, Lingkungan Kerja Fisik, dan Motivasi Kerja

A. PENDAHULUAN

1. Latar Belakang.

Setiap pembicaraan tentang organisasi tentu tidak akan terlepas dari kepemimpinan. Sebuah organisasi dijalankan dan diatur oleh seorang pemimpin. Pemimpin yang ideal di tuntut harus bisa memberikan dan menunjukan keteladanan hidupnya. Lebih jauh lagi pemimpin di haruskan memiliki pengaruh bagi bawahannya atau anggotanya. Salah satu contoh yang tidak bisa ditawar-tawar adalah pengaruh seorang pemimpin bagi motivasi kerja karyawannya. Dengan kata lain, pemimpin harus menjadi corong, bertindak sebagai mercusuar yang selalu menerangi, menjadi tongkat penuntun, menjadi pelita bernyala dan bahkan mesti menjadi contoh bagi karyawannya.

Teori-teori kepemimpinan dimaksud untuk mengetahui unsurunsur apa saja yang membentuk pribadi seseorang sehinggga diketahui sebagai seorang pemimpin yang disegani dan diikuti kepemimpinannya.

Untuk itu permasalahan yang penting bagi suatu organisasi adalah bagaimana memberikan motivasi kepada pegawai agar mampu, cakap, dan terampil untuk melakukan pekerjaan dengan baik dan mau bekerja dengan giat untuk mencapai hasil yang maksimal. Pentingnya motivasi karna motivasi adalah hal yang menyebabkan, menyalurkan dan mendukung prilaku manusia supaya mau bekerja giat dan aktivitas mencapai hasil yang optimal.

Di lain pihak kondisi lingkungan kerja fisik pun sangat berpengaruh terhadap motivasi kerja karyawan. Lingkungan kerja fisik merupakan suatu lingkungan dimana para karyawan bekerja dan dapat mempengaruhi mereka dalam menjalankan tugas - tugas yang dibebankan. Faktor-faktor yang termasuk lingkungan kerja fisik adalah pewarnaan, kebersihan, pertukaran udaara, penerangan, musik, kebisingan dan ruang gerak.

Lingkungan kerja yang nyaman dan sarana-sarana pendukung yang memadai adalah salah satu faktor yang sangat dibutuhkan pegawai dalam menjalankan pekerjaannya. 
Walaupun lingkungan kerja termasuk salah satu faktor yang penting dalam meningkatkan semangat kerja, tetapi masih banyak organisasi atau perusahaan yang belum begitu memperhatikannya.

Berdasarkan kondisi diatas, maka penulis terdorong untuk mencoba melakukan penelitian guna memberikan masukan-masukan pada perusahaan CV. Sedulur Palembang dengan judul "Pengaruh kepemimpinan dan lingkungan kerja fisik terhadap motivasi kerja karyawan pada CV. Sedulur Palembang".

\section{Perumusan Masalah.}

Berdasarkan latar belakang dan identifikasi masalah serta batasan masalah diatas maka dapat dirumuskan penelitian sebagai berikut :

1. Apakah terdapat pengaruh kepemimpinan dan lingkungan kerja fisik terhadap motivasi kerja karyawan pada CV. Sedulur Palembang?

2. Apakah terdapat pengaruh kepemimpinan terhadap motivasi kerja karyawan pada CV. Sedulur Palembang?

3. Apakah terdapat pengaruh lingkungan kerja fisik terhadap motivasi kerja karyawan pada CV. Sedulur Palembang?

\section{Tujuan dan Kegunaan} Penelitian.

a. Tujuan Penelitian.

1. Untuk mengetahui pengaruh kepemimpinan dan lingkungan kerja fisik terhadap motivasi kerja karyawan pada CV. Sedulur Palembang.

2. Untuk mengetahui pengaruh kepemimpinan terhadap motivasi kerja karyawan pada CV. Sedulur Palembang.
3. Untuk mengetahui pengaruh lingkungan kerja fisik terhadap motivasi kerja karyawan pada CV. Sedulur Palembang.

b. Kegunaan Penelitian.

1. Penelitian ini berguna untuk menerapkan dan mengaplikasikan teori sumber daya manusia serta menambah wawasan penulis dalam mengembangkan kreatifitasdan pengetahuan yang mungkin tidak didapat di bangku kuliah.

2. Dari hasil penelitian ini diharapkan dapat digunakan sebagai alternatif maupun dasar pertimbangan oleh pimpinan maupun staf pada CV. Sedulur Palembang untuk meningkatkan motivasi kerja karyawan.

3. Hasil penelitian ini dapat dipakai sebagai bahan bacaan ilmiah diperpustakaan dan juga dapat dipakai sebagai bahan referensi bagi mahasiswa yang meneliti masalah sejenis.

\section{B. LANDASAN TEORI}

\section{Pengertian Motivasi Kerja.}

Kata motivasi yang sudah baku menjadi Bahasa Indonesia berasal dari Bahasa Inggris yaitu motivation. Motivation itu sendiri berasal dari bahasa latin movere yang berarti to move (bergerak atau berpindah). Menurut Luthans (1995 : 141) bahwa motivasi adalah suatu proses yang mulai dilakukan oleh seseorang yang disebabkan adanya kebutuhan, baik kebutuhan psikologis maupun fisiologis sehingga menggerakkan perilaku dan menimbulkan dorongan untuk mencapai tujuan.

Lain halnya pendapat yang dikemukakan oleh Stoner, Freeman, Gilbert (1996 : 134-135) yang menyatakan bahwa motivasi merupakan karakteristik psikologis yang ada pada diri manusia yang akan 
memberikan kontribusi pada tingkat komitmen seseorang dalam melakukan suatu aktivitas sehingga tercapainya suatu tujuan yang diinginkan, sedangkan pada bagian lain dikatakan juga bahwa motivasi adalah suatu proses manajemen untuk mempengaruhi perilaku seseorang berdasarkan pengetahuan terhadap apa yang membuat perusahaan atau para manajer harus memahami asumsi dasar tentang motivasi.

Definisi diatas menunjukkan bahwa dengan meningkatnya motivasi kerja, maka pekerjaan akan lebih cepat dapat diselesaikan. Kerusakan akan dapat dikurangi, absensi akan dapat diperkecil sehingga dengan ini semua motivasi akan dapat ditingkatkan. Bahkan turun/rendahnya motivasi dan gairah kerja sebenarnya dapat diketahui dengan jalan melihat indikasi-indikasi yang mungkin timbul yaitu antara lain turun/rendahnya motivasi kerja, tingkat absensi yang naik/tinggi dan sebagainya.

\section{Pengertian Kepemimpinan.}

Kepemimpinan adalah sifat, karakter, atau cara seseorang dalam upaya membina dan menggerakkan seseorang atau sekelompok orang agar mereka bersedia, komitmen dan setia untuk melaksanakan kegiatan sesuai dengan tugas dan tanggung jawab untuk mewujudkan tujuan perusahaan yang telah ditetapkan sebelumnya. (I Gusti Ngurah Gorda, 2006 : 157).

Kepemimpinan adalah suatu proses penggunaan pengaruh positif terhadap orang lain untuk melakukan usaha lebih banyak dalam sejumlah tugas atau mengubah perilakunya (Kenneth N. Wexley dan Gary A Yuki, 2003 : 189).

Kepemimpinan kadangkala diartikan sebagai pelaksana otoritas dan pembuatan keputusan.
Kepemimpinan diartikan juga suatu inisiatif untuk bertindak yang menghasilkan suatu pola yang konsisten dalam rangka mencari jalan pemecahan dari suatu persoalan bersama. Lebih jauh lagi dirumuskan bahwa kepemimpinan itu adalah aktivitas untuk mempengaruhi orangorang supaya diarahkan mencapai tujuan organisasi (Miftah Thoha, 2003 : 5).

Dari pengertian beberapa ahli tersebut dapat dikatakan kepemimpinan adalah sifat atau karakter, atau kegiatan atasan atau pimpinan untuk mempengaruhi perilaku sekelompok karyawan secara positif, membimbing dan mengarahkannya agar bekerja dengan lancar sehingga tujuan perusahaan dapat tercapai dengan baik.

\section{Pengertian Lingkungan Kerja.}

Lingkungan kerja fisik adalah keseluruhan atau setiap aspek dari gejala dan sosial-kultural yang mengelilingi atau mempengaruhi individu. (Komarudin, 2002 : 142).

Lingkungan kerja fisik adalah segala sesuatu yang ada disekitar para pekerja yang dapat mempengaruhi dirinya dalam menjalankan tugas-tugas yang dibebankan, kebersihan, musik dan lain-lain (Alex. S. Nitisemito 2002 : 183).

Berdasarkan definisi tersebut dapat dinyatakan lingkungan kerja fisik adalah segala sesuatu yang ada di sekitar karyawan bekerja yang mempengaruhi karyawan dalam melaksanakan beban tugasnya. Masalah lingkungan kerja dalam suatu organisasi sangatlah penting, dalam hal ini diperlukan adanya pengaturan maupun penataan faktor-faktor lingkungan kerja fisik dalam penyelenggaraan aktivitas organisasi. 
4. Penelitian Terdahulu.

Penelitian sebelumnya berjudul "Pengaruh Kepemimpinan dan Lingkungan Kerja Fisik Terhadap Semangat Kerja Karyawan Pada KUD Timpag" oleh Kade Agus Sukaryanata. NIM: 02.32.121.080, Fakultas Ekonomi Jurusan Manajemen, Universitas Warmadewa, Tahun 2006. Tujuan penelitian ini adalah untuk mengetahui pengaruh kepemimpinan dan lingkungan kerja fisik terhadap semangat kerja karyawan pada KUD Timpag. Sampel yang digunakan dalam penelitian ini sebanyak 39 orang. Hasil penelitian menunjukkan bahwa : regresi linier berganda diperoleh persamaan garis $Y=-9,3804$ $+0,6213 X_{1}+0,4646 X_{2}$ yang berarti bahwa kepemimpinan dan lingkungan kerja fisik secara simultan berpengaruh terhadap semangat kerja karyawan.

Penelitian kedua berjudul "Pengaruh Kepemimpinan dan Lingkungan Kerja Fisik Terhadap Semangat Kerja Karyawan Pada PT BPR Penebel" oleh Ni Komang Yuni. NIM: 21.32.121.320, Fakultas Ekonomi Jurusan Manajemen, Universitas Warmadewa, Tahun 2005. Tujuan penelitian ini adalah untuk mengetahui pengaruh kepemimpinan dan lingkungan kerja fisik terhadap semangat kerja karyawan pada PT BPR Penebel. Hasil penelitiannya menunjukkan bahwa : regresi linier berganda diperoleh persamaan garis $Y$ $=1,3519+0,8541 \mathrm{X}_{1}+0,0991 \mathrm{X}_{2}$ yang berarti bahwa kepemimpinan dan lingkungan kerja fisik secara simultan mempengaruhi semangat kerja karyawan dimana kepemimpinan berpengaruh besar dari pada lingkungan kerja fisik.

Kesamaan penelitian terdahulu dengan penelitian sekarang adalah:

a. Pada penelitian sebelumnya dan peneiltian sekarang menggunakan obyek yang sama yaitu :

kepemimpinan, lingkungan kerja fisik dan motivasi kerja karyawan.

b. Data untuk keperluan analisis diperoleh dengan menyebar kuisioner kepada konsumen yang dijadikan responden.

Perbedaan penelitian terdahulu dengan penelitian sekarang adalah

a. Tempat penelitian terdahulu pada KUD Timpag di Tabanan, sedangkan penelitian sekarang pada CV. Sedudur di Palembang.

b. Sampel penelitian terdahulu adalah 39 orang, sedangkan penelitian sekarang adalah 83 orang.

\section{Kerangka Pemikiran.}

Untuk mengetahui gambaran isi secara keseluruhan, dibuatlah skema kerangka pemikiran seperti pada gambar berikut ini :

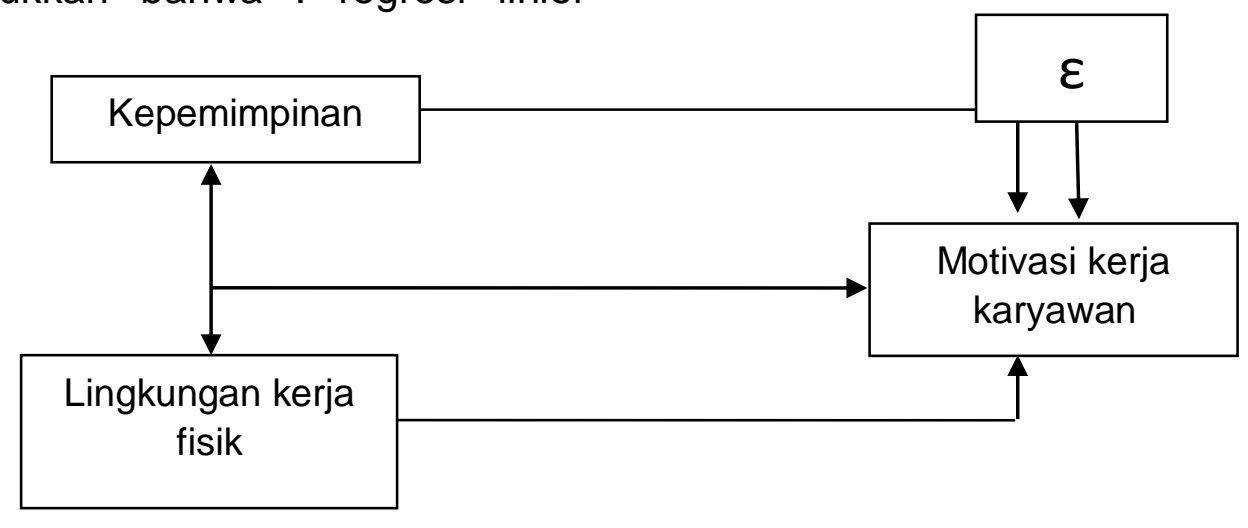

Gambar 1. Kerangka Pemikiran Penelitian 


\section{Hipotesis Penelitian.}

pemikiran penelitian yang dikemukakan diatas, maka diambil dugaan sementara atau hipotesis sebagai berikut :

1. Kepemimpinan dan lingkungan kerja fisik mempunyai pengaruh positif yang signifikan terhadap motivasi karyawann pada CV. Sedulur Palembang.

2. Kepemimpinan mempunyai pengaruh positif dan signifikan terhadap motivasi kerja karyawan CV Sedulur Palembang.

3. Lingkungan kerja fisik mempunyai pengaruh positif dan signifikan terhadap motivasi kerja karyawan pada CV. Sedulur Palembang

\section{METODE PENELITIAN}

1. Populasi dan Teknik Sampling.

Dalam penelitian ini tehnik pengambilan sample yang dilakukan secara stratified selanjutnya ditarik secara random dengan menggunakan simple random sampling atau pengambilan secara acak sederhana. Menurut Arikunto apabila populasi dibawah 100, sebaiknya diambil semua, apabila populasi diatas 100, sebaiknya diambil $10-15 \%$ atau 20 $25 \%$ atau lebih. Berdasarkan pendapat tersebut maka besarnya sampel yang diambil yaitu sebanyak 83 orang, dengan rincian 33 orang digunakan untuk uji coba instrument dan 50 orang untuk sampel data.

\section{Definisi Operasional Variabel Penelitian.}

a. Motivasi Kerja Karyawan.

Motivasi kerja karyawan, adalah sikap mental dari individu maupun kelompok yang menunjukkan kesungguhan didalam melaksanakan pekerjaan sehingga mendorong untuk bekerja lebih baik yang ditunjukkan.

Tabel 1.

Kisi-kisi dan Penyebaran Butir Instrument Variabel Motivasi Kerja ( $Y$ )

\begin{tabular}{|c|c|c|}
\hline Dimensi & Indikator & $\begin{array}{l}\text { No. } \\
\text { Butir }\end{array}$ \\
\hline Pemberian gaji & $\begin{array}{l}\text { a. Pemberian gaji yang cukup } \\
\text { b. Pemberi gaji sesuai dengan pengalaman }\end{array}$ & $1,2,3$ \\
\hline Kebutuhan rohani & $\begin{array}{l}\text { a. Karyawan diberikan waktu untuk beribadah } \\
\text { b. Hubungan antara karyawan dan atasan dan } \\
\text { sesama karyawan baik }\end{array}$ & $4,5,6$ \\
\hline $\begin{array}{l}\text { Menciptakan } \\
\text { suasana santai }\end{array}$ & $\begin{array}{l}\text { a. Suasana santai dapat mengurangi ketegangan } \\
\text { b. Suasana santai dapat meningkatkan motivasi dan } \\
\text { gairah kerja }\end{array}$ & $7,8,9$ \\
\hline $\begin{array}{l}\text { Perasaan aman } \\
\text { menghadapi masa } \\
\text { depan }\end{array}$ & $\begin{array}{l}\text { a. Perusahaan memberikan jaminann kesehatan } \\
\text { b. Pemberian jaminan kesehatan dapat memberikan } \\
\text { rasa aman }\end{array}$ & $\begin{array}{l}10,11,1 \\
2\end{array}$ \\
\hline Loyalitas karyawan & $\begin{array}{l}\text { a. Perusahaan sudah memberikan penghargaan } \\
\text { kepada karyawan yang berpatisipasi } \\
\text { b. Penghargaan dapat memberikan motivasi kerja } \\
\text { karyawan }\end{array}$ & $\begin{array}{l}13,14,1 \\
5\end{array}$ \\
\hline $\begin{array}{l}\text { Sekali-kali } \\
\text { karyawan perlu } \\
\text { diajak berundung }\end{array}$ & $\begin{array}{l}\text { a. Tipe kepemimpinan } \\
\text { b. Karyawan selalu diajak berunding }\end{array}$ & $\begin{array}{l}16,17,1 \\
8\end{array}$ \\
\hline
\end{tabular}




\begin{tabular}{|l|l|l|}
\hline $\begin{array}{l}\text { Pemberian insentif } \\
\text { yang terarah }\end{array}$ & $\begin{array}{l}\text { a. Pemberian insentif bagi karyawan yang berprestasi } \\
\text { b. Insentif yang diberikan sesuai dengan kebutuhan }\end{array}$ & $19,20,2$ \\
& $\begin{array}{l}\text { c. Insentif yang diberikan meningkatkan semangat } \\
\text { kerja }\end{array}$ & $1,22,23$ \\
\hline
\end{tabular}

b. Kepemimpinan.

Kepemimpinan adalah

kemampuan yang dimiliki oleh tiap-

tiap pemimpin untuk

menggerakkan orang lain dengan

memimpin, membimbing, mengawasi, memberikan contoh, dan mengarahkan orang lain untuk bekerja dengan baik sehingga tujuan perusahaan dapat tercapai.

Tabel 2.

Kisi-kisi dan Penyebaran Butir Instrument Variabel Kepemimpinan $\left(\mathbf{X}_{1}\right)$

\begin{tabular}{|c|c|c|}
\hline Dimensi & Indikator & No. Butir \\
\hline Pembinaan & $\begin{array}{l}\text { a. Pimpinan selalu membuat perencanaan program kerja } \\
\text { b. Pimpinan selalu memberikan arahan kepada karyawan } \\
\text { c. Pimpinan selau memberikan pembinaan kepada } \\
\text { karyawan } \\
\text { d. Pimpinan memberikan kepada karyawan yang } \\
\text { berprestasi } \\
\text { e. Pimpinan memberikan sanki kepada karyawan } \\
\text { f. Pimpinan memberikan kesempatan karyawan untuk } \\
\text { maju }\end{array}$ & $\begin{array}{c}1,2,3,4,5,6 \\
, 7,8,9\end{array}$ \\
\hline Teladan & $\begin{array}{l}\text { a. Pimpinan memberikan pujian kepada karyawan yang } \\
\text { semangat } \\
\text { b. Pimpinan selalu membangun suasanan keakraban } \\
\text { c. Pimpinan yang selalu memberikan contoh yang baik } \\
\text { kepada karyawan } \\
\text { d. Pimpinan selalu memperhatikan kepentingan } \\
\text { organisasi daripada pribadi }\end{array}$ & $\begin{array}{c}10,11,12,1 \\
3, \\
14,15,16\end{array}$ \\
\hline Perintah & $\begin{array}{l}\text { a. Pimpinan selalu memberikan arahan terhadap tugas } \\
\text { yang akan dilaksanakan } \\
\text { b. Pimpinan memberikan kesempatan karyawan untuk } \\
\text { meningkatkan keterampilan } \\
\text { c. Pimpinan selalu melibatkan bawahan dalam membuat } \\
\text { rencana kerja }\end{array}$ & $\begin{array}{c}17,18,19,2 \\
0\end{array}$ \\
\hline
\end{tabular}

c. Lingkungan Kerja Fisik.

Lingkungan kerja fisik, adalah segala sesuatu yang ada disekitar karyawan.

Tabel 3.

Kisi-kisi dan Penyebaran Butir Instrument Variabel Lingkungan Kerja Fisik $\left(X_{2}\right)$

\begin{tabular}{|c|l|c|}
\hline Dimensi & \multicolumn{1}{|c|}{ Indikator } & No. Butir \\
\hline Pewarnaan & $\begin{array}{l}\text { Penggunaan warna dalam ruangan kerja sudah } \\
\text { disesuaikan agar dapat membantu pekerjaan yang } \\
\text { memerlukan ketelitian }\end{array}$ & $1,2,3$ \\
\hline Teladan & $\begin{array}{l}\text { Penerangan lampu dan masuknya sinar ke dalam } \\
\text { ruangan kerja karyawan sudah selesai }\end{array}$ & $4,5,6,7$ \\
\hline
\end{tabular}




\begin{tabular}{|c|c|c|}
\hline Udara & $\begin{array}{l}\text { - Perusahaan telah memasang ventilasi yang baik dan } \\
\text { alat bantu berupa AC atau kipas angin dalam setiao } \\
\text { ruangan kerja karyawan }\end{array}$ & $8,9,10$ \\
\hline Suara bising & $\begin{array}{l}\text { - Perusahaan telah mengurangi tingkat kebisingan } \\
\text { suara di lingkungan kerja dengan memasang bahan } \\
\text { kedap suara (Teknologi White Sound) } \\
\text { Perusahaan telah melakukan antisipasi untuk } \\
\text { menghindarkan suara-suara gaduh agar jauh dari } \\
\text { tempat karyawan melakukan pekerjaan }\end{array}$ & $\begin{array}{c}11,12,13,1 \\
4\end{array}$ \\
\hline Ruang Gerak & $\begin{array}{l}\text { - Perusahaan yang telah mengatur ruang gerak baik } \\
\text { karyawannya dalam melakukan mobilitas kegiatannya }\end{array}$ & 15 \\
\hline Keamanan & $\begin{array}{l}\text { - Perusahaan telah memperhatikan tingkat keamanan } \\
\text { ditempat kerja sebagai faktor penunjang kinerja } \\
\text { dalam perusahaan } \\
\text { - Perusahaan selalu merenovasi bangunan setiap } 5 \\
\text { tahun sekali } \\
\text { - Perusahaan telah menyediakan peralatan yang } \\
\text { canggih untuk mendukung aktivitas karyawan }\end{array}$ & $16,17,18$ \\
\hline Kebersihan & $\begin{array}{l}\text { - Kondisi lingkungan kerja diperusahaan tempat } \\
\text { bekerja tertata rapi }\end{array}$ & 19,20 \\
\hline
\end{tabular}

3. Teknik Pengujian Instrumen.

a. Validitas.

Untuk mengukur validitas instrumen kepemimpinan, lingkungan kerja fisik dan motivasi kerja karyawan dilakukan uji coba instrumen dengan menggunakan pegawai sebagai responden. Validitas instrumen ketiga variabel dicari dengan cara menghitung data dengan rumus Person Product Moment dalam program SPSS.

b. Reliabilitas.

Untuk pengujian reabilitas ketiga instrument kepemimpinan, lingkungan kerja fisik dan motivasi kerja karyawan dilakukan dengan metode internal consistency dengan teknik belah dua (split half) dari Sperman Brown. Langkah pertama setelah diuji coba dan ditemukan validitasny, item-item yang valid dikumpulkan, dan itemitem yang tidak valid dibuang. Langkah kedua, item-item yang valid dibelah menjadi dua secara acak, dilakukan penskoran tiap item masing-masing kelompok sehingga ditemukan skor total tiap belahan. Langkah ketiga, dilakukan antara jumlah skor belahan awal dan belahan akhir.

4. Teknik Analisis Data.

a. Analisis Deskriptif.

Analisis ini dipilih dan dipergunakan dengan maksud untuk menggambarkan karakteristik penyebaran skor setiap variabel dengan menghitung rata-rata mean, simpangan baku, skor tertinggi, skor terendah, serta visualisasi data berupa grafik dan tabel.

b. Analisis Inferensial.

1) Analisis Regresi Linear Berganda.

Analisis regresi pada dasarnya adalah studi mengenai ketergantungan variabel terikat dengan satu atau lebih variabel bebas dengan tujuan untuk memprediksi nilai rata-rata variabel terikat berdasarkan nilai variabel bebas yang di ketahui (Gozhali,2001:43). 
Persamaan garis regresi linier berganda dapat ditulis sebagai berikut:

$$
Y=a+b_{1} X_{1}+b_{2} X_{2}+e
$$

2) Analisis Korelasi Berganda.

Analisis ini digunakan untuk mengetahui derajat hubungan antara variable. Untuk mengetahui derajat hubungan antara varabel kepemimpinan $\left(\mathrm{X}_{1}\right)$ dan lingkungan kerja fisik $\left(\mathrm{X}_{2}\right)$ dengan variabel motivasi kerja kariawan (Y), dengan rumus:

$$
\mathbf{R}=\sqrt{\frac{b_{1} \sum x_{1} y+b_{1} \sum x_{2} y}{\sum y}}
$$

3) Analisis Determinasi.

Analisis ini digunakan untuk mengetahui variasi hubungan variabel terikat yang disebabkan oleh variabel bebas dengan rumus sebagai berikut (Riduwan, $2005: 228)$ :

$$
D=R^{2} .100 \%
$$

\section{Uji Hipotesis.}

a. Uji Signifikansi Simultan (Uji

Statistik F).

Dipergunakan untuk menguji nyata tidaknya pengaruh variabel bebas secara simultan terhadap variabel terkait (Imam Ghozali, 2001 ; 46). Langkah-langkah penyelesaian : Ho : b1, b2 = 0 artinya tidak ada pengaruh yang signifikan antara kepemimpinan dan lingkungan kerja fisik secara simultan terhadap motifasi kerja kariawan.

Ho : b1, b2 > 0 artinya ada pengaruh yang signifikan antara kepemimpinan

dan lingkungan kerja fisik secara simultan terhadap motifasi kerja kariawan

b. Uji Signifikansi Parameter Individual (Uji Statistik t).

Uji $t$ dipergunakan untuk mengetahui pengaruh antara variabel kepemimpinan $\left(X_{1}\right)$ dan lingkungan kerja fisik $\left(X_{2}\right)$ dengan motivasi kerja karyawan $(\mathrm{Y})$ secara parsial.

Langkah - langkah penyelesaian :

(1). Pengujian koefisien regresi $b_{1}$

Penentuan formulasi hipotesis sebagai berikut :

$\mathrm{H}_{0}: \mathrm{b}_{1}=0$ berarti tidak ada pengaruh positif dan signifikan secara parsial antara kepemimpinan $\left(\mathrm{X}_{1}\right)$ dengan motivasi kerja karyawan $(\mathrm{Y})$

$\mathrm{H}_{0}: \mathrm{b}_{1}>0$ berarti ada pengaruh positif dan signifikan secara parsial antara kepemimpinan $\left(\mathrm{X}_{1}\right)$ dengan motivasi kerja karyawan $(\mathrm{Y})$.

Dengan ketentuan pengujian alpha $5 \%$ maka t-tabel $=\mathrm{t}_{0,05}$; $(n-k-1) \quad k=$ jumlah variable. Adapun kriteria pengujiannya yaitu :

$\mathrm{H}_{0}$ diterima apabila $\mathrm{t}$-hit $\leq \mathrm{t}$ tabel

$\mathrm{H}_{0}$ ditolak apabila t-hit $>\mathrm{t}$-tabel Sedangkan untuk penentuan thitung adalah :

t-hitung1 $=\frac{b 1}{S b 1}$

(2). Pengujian koefisien regresi $b_{2}$ Penentuan formulasi hipotesis sebagai berikut : 


$$
\begin{aligned}
& \mathrm{H}_{0}: \mathrm{b}_{2}=0 \text { berarti tidak ada } \\
& \text { pengaruh positif } \\
& \text { dan signifikan } \\
& \text { secara parsial } \\
& \text { antara lingkungan } \\
& \text { kerja fisik }\left(\mathrm{X}_{2}\right) \\
& \text { dengan motivasi } \\
& \text { kerja karyawan }(\mathrm{Y}) \\
& \mathrm{H}_{0}: \mathrm{b}_{2}>0 \text { berarti ada } \\
& \text { pengaruh positif } \\
& \text { dan signifikan } \\
& \text { secara parsial } \\
& \text { antara lingkungan } \\
& \text { kerja fisik }\left(\mathrm{X}_{2}\right) \\
& \text { dengan motivasi } \\
& \text { kerja karyawan } \\
& \text { (Y). }
\end{aligned}
$$

Dengan ketentuan pengujian alpha $5 \%$ maka t-tabel $=\mathrm{t}_{0,05}$; (n-k-1) $\mathrm{k}=$ jumlah variable. Adapun kriteria pengujiannya yaitu :

$\mathrm{H}_{0}$ diterima apabila $\mathrm{t}$-hit $\leq \mathrm{t}-$ tabel

$\mathrm{H}_{0}$ ditolak apabila t-hit $>\mathrm{t}$-tabel Sedangkan untuk penentuan thitung adalah :

$$
\text { t-hitung2 }=\frac{b 2}{S b 2}
$$

\section{HASIL DAN PEMBAHASAN}

1. Hasil Penelitian.

a. Uji Validitas.

1) Variabel Motivasi Kerja ( $Y$ ). Hasil pengolahan data untuk variabel motivasi kerja dari 23 butir pertanyaan diperoleh nilai $r$ hitung lebih besar dari $r$ tabel 0,279 (tabel r Product Moment) sehingga semua pertanyaan dinyatakan valid. Untuk penelitian sebenarnya variable motivasi kerja menggunakan semua butir pertanyaan.

2) Variabel Kepemimpinan $\left(X_{1}\right)$. Hasil pengolahan data untuk variabel kepemimpinan dari 20 butir pertanyaan diperoleh nilai $r$ hitung lebih besar dari $r$ tabel
0,279 (tabel r Product Moment) sehingga semua pertanyaan dinyatakan valid. Untuk penelitian sebenarnya variable kepemimpinan menggunakan semua butir pertanyaan.

3) Variabel Lingkungan Kerja Fisik $\left(\mathrm{X}_{2}\right)$.

Hasil pengolahan data untuk variabel lingkungan kerja fisik dari 20 butir pertanyaan diketahui butir pertanyaan nomor 7 memiliki nilai $r$ hitung 0,248 lebih kecil dari $r$ tabel 0,279, sehingga dinyatakan tidak valid dan dibuang dari kuisioner. Untuk penelitian sebenarnya variable lingkungan kerja fisik menggunakan 19 butir pertanyaan.

b. Uji Reliabilitas.

Dalam uji reliabilitas digunakan metode split-half. Metode split-half adalah suatu metode yang dilakukan dengan cara mengkorelasikan antara total skor pada item pertanyaan yang ganjil dengan total skor pada item pertanyaan genap. Kemudian dilanjutkan dengan pengujian rumus Spearman-Brown.

\section{Pembahasan.}

a) Uji Persyaratan Analisis.

1. Uji Normalitas.

Dalam penelitian ini, taraf signifikansi yang digunakan adalah $5 \%$ atau $\alpha=0,05$, jadi $\mathrm{Ho}$ diterima jika Asymp. Signifikansi lebih besar dari 0,05 dan Ho ditolak Asymp. Signifikansi lebih kecil dari 0,05.

Dari hasil perhitungan diperoleh Asymp. Signifikansi untuk ketiga variabel masing-masing sebesar $0,945,0,407$, dan 0,460 lebih besar dari 0,05, maka Ho diterima. Artinya pengujian menunjukkan 
data untuk ketiga variabel berdistribusi normal.

2. Uji Homogenitas.

Pengujian homogenitas pada penelitian ini dilakukan dengan mengunakan Uji Chi-Square dengan menetapkan signifikansi 5 $\% \quad(\alpha=0,05)$. Interpretasi homogenitas data dihitung berdasarkan nilai Asymtotic Significance yang diperoleh. Jika Asymp. Sig $>\alpha=0,05$ maka data dinyatakan homogen.

Dari hasil perhitungan diperoleh Asymp. Signifikansi untuk ketiga variabel masing-masing sebesar 0,987, 0,910, dan 0,749 lebih besar dari 0,05, maka dapat disimpulkan bahwa data populasi untuk ketiga variabel diatas memiliki varians homogen.

3. Uji Linieritas.

a. Hubungan Motivasi Kerja (Y) dengan Kepemimpinan $\left(\mathrm{X}_{1}\right)$.
Dari hasil perhitungan uji linearitas antara motivasi kerja dengan kepemimpinan diperoleh nilai deviation from linearity sebesar 0,367, nilai yang diperoleh lebih besar dari a sebesar $5 \%$, maka Ho diterima artinya variabel motivasi kerja dengan kepemimpinan mempunyai hubungan yang linear.

b. Hubungan Motivasi Kerja (Y) dengan Lingkungan Kerja Fisik $\left(\mathrm{X}_{2}\right)$.

Dari hasil perhitungan uji linearitas antara motivasi kerja dengan lingkungan kerja fisik diperoleh nilai sebesar 0,890, nilai yang diperoleh lebih besar dari a sebesar 5\%, maka Ho diterima artinya variabel motivasi kerja dengan lingkungan kerja fisik mempunyai hubungan yang linear.

b) Analisis Regresi Linear Berganda.

Pengaruh kepemimpinan (X1) dan lingkungan kerja fisik (X2) terhadap motivasi kerja (Y).

Tabel 4.

Analisis Regresi Linear Berganda Variabel (X1), (X2), dan (Y)

\begin{tabular}{|c|c|c|c|c|c|c|}
\hline \multirow[b]{2}{*}{ Mode } & & \multicolumn{2}{|c|}{$\begin{array}{l}\text { Unstandardized } \\
\text { Coefficients }\end{array}$} & \multirow{2}{*}{$\begin{array}{c}\text { Standardized } \\
\text { Coefficients } \\
\text { Beta }\end{array}$} & \multirow[b]{2}{*}{$t$} & \multirow[b]{2}{*}{ Sig. } \\
\hline & & B & Std. Error & & & \\
\hline \multirow[t]{3}{*}{1} & (Constant) & 19,327 & 8,720 & & 2,216 &, 032 \\
\hline & Kepemimpinan (X1) & ,351 & ,119 & ,337 & 2,940 & 005 \\
\hline & $\begin{array}{l}\text { Lingkungan Kerja } \\
\text { Fisik (X2) }\end{array}$ &, 564 & ,125 & ,518 & 4,525 & ,004 \\
\hline
\end{tabular}

Dari hasil perhitungan melalui program SPSS diatas, diperoleh nilai koefisien regresi untuk constanta = 19,327 koefisien kepemimpinan $=0$, 351 dan koefisien lingkungan kerja fisik $=0,564$. Sehingga persamaan regresi berganda dapat dituliskan sebagai berikut $Y=19,327+$ $0,351 X 1+0,564 X 2+e$

Dimana :

- Konstanta sebesar 19,327 menyatakan bahwa jika mengabaikan kepemimpinan dan 
lingkungan kerja fisik maka skor motivasi kerja adalah 19, 327.

- Koefisien regresi X1 sebesar 0,351 menyatakan bahwa setiap penambahan satu satuan skor kepemimpinan akan meningkatkan skor motivasi kerja sebesar 0,351 dengan menjaga skor lingkungan kerja fisik (X2) tetap/konstan.

- Koefisien regresi X2 sebesar 0,564 menyatakan bahwa setiap penambahan satu satuan skor linkungan kerja fisik akan meningkatkan skor motivasi kerja sebesar 0,564 dengan menjaga skor kepemimpinan (X1) tetap/konstan.

c) Analisis Korelasi.

Hubungan kepemimpinan (X1) dan lingkungan kerja fisik (X2) dengan motivasi kerja (Y).

d) Pengujian Hipotesis Statistik.

Pengaruh kepemimpinan (X1) dan lingkungan kerja fisik (X2) dengan motivasi kerja (Y).

Analisis Uji Hipotesis Statistik Variabel (X1), (X2), dan (Y)

\begin{tabular}{|c|c|c|c|c|c|c|}
\hline \multicolumn{2}{|c|}{ Model } & $\begin{array}{l}\text { Sum of } \\
\text { Squares }\end{array}$ & $d f$ & Mean Square & $\mathrm{F}$ & Sig. \\
\hline \multirow[t]{3}{*}{1} & Regression & 2309,954 & 2 & 1154,977 & 32,021 &, $000^{a}$ \\
\hline & Residual & 1695,266 & 47 & 36,069 & & \\
\hline & Total & 4005,220 & 49 & & & \\
\hline
\end{tabular}

Dari hasil perhitungan tabel diatas diperoleh nilai dari taraf signifikansi sebesar 0,000 atau signifikansi yang diperoleh lebih kecil dari $\alpha=0,05$ artinya Ho ditolak, Ha diterima. Hal ini
Berdasarkan hasil perhitungan melalui program SPSS dapat diinterpretasikan sebagai berikut :

- Pada Model Summary diperoleh nilai $R=0,759$ yang berarti bahwa hubungan atau tingkat asosiasi variabel bebas yaitu kepemimpinan dan lingkungan kerja fisik dengan variabel terikat yaitu motivasi kerja adalah sangat kuat positif.

- Angka $R$ Square (nilai koefisien determinasi $\left(R^{2}\right)$ sebesar 0,577 memberikan makna bahwa secara simultan atau serentak kedua variabel bebas kepemimpinan dan lingkungan kerja fisik hanya mampu menjelaskan perubahan terhadap variabel motivasi kerja sebesar 57,7 \%, sedangkan sisanya dijelaskan oleh variabelvariabel lain yang tidak termasuk dalam penelitian ini atau error $(\boldsymbol{e})$.

Tabel 5 
Pengaruh kepemimpinan $(\mathrm{X} 1)$ dengan motivasi kerja $(\mathrm{Y})$.

Tabel 6.

Analisis Uji Hipotesis Statistik Variabel (X1) dan (Y)

\begin{tabular}{|c|c|c|c|c|c|c|}
\hline \multirow{2}{*}{\multicolumn{2}{|c|}{ Model }} & \multicolumn{2}{|c|}{$\begin{array}{l}\text { Unstandardized } \\
\text { Coefficients }\end{array}$} & \multirow{2}{*}{$\begin{array}{c}\text { Standardized } \\
\text { Coefficients } \\
\text { Beta }\end{array}$} & \multirow[b]{2}{*}{$t$} & \multirow[b]{2}{*}{ Sig. } \\
\hline & & $B$ & Std. Error & & & \\
\hline \multirow[t]{3}{*}{1} & (Constant) & 19,327 & 8,720 & & 2,216 & ,032 \\
\hline & Kepemimpinan (X1) & ,351 & ,119 & ,337 & 2,940 & ,005 \\
\hline & $\begin{array}{l}\text { Lingkungan Kerja } \\
\text { Fisik (X2) }\end{array}$ &, 564 & , 125 &, 518 & 4,525 &, 004 \\
\hline
\end{tabular}

Dari hasil perhitungan tabel diatas terlihat bahwa pada kolom signifikansi untuk baris kepemimpinan diperoleh 0,005 atau signifikansi yang diperoleh lebih kecil dari $\alpha=0,05$ artinya Ho ditolak, Ha diterima. Hal ini dapat diartikan terdapat pengaruh yang signifikan antara kepemimpinan dengan motivasi kerja karyawan $\mathrm{CV}$. Sedulur Palembang.

\section{Pengaruh lingkungan kerja fisik ( $\mathrm{X} 2)$ dengan motivasi kerja $(\mathrm{Y})$.}

Tabel 7.

\section{Analisis Uji Hipotesis Statistik Variabel (X2) dan (Y)}

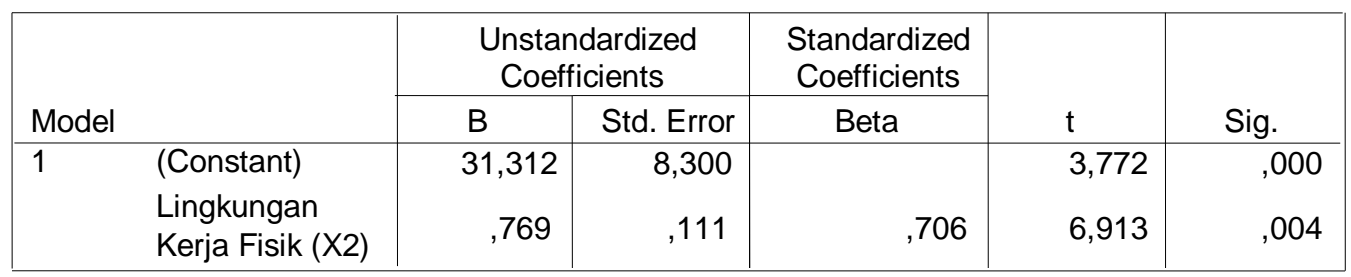

Dari hasil perhitungan tabel diatas terlihat bahwa pada kolom signifikansi untuk baris lingkungan kerja fisik diperoleh 0,004 atau signifikansi yang diperoleh lebih kecil dari $\alpha=0,05$ artinya Ho ditolak, Ha diterima. Hal ini dapat diartikan terdapat pengaruh yang signifikan antara lingkungan kerja fisik dengan motivasi kerja karyawan CV. Sedulur Palembang.

\section{E. KESIMPULAN DAN SARAN}

1. Kesimpulan.

Berdasarkan hasil analisis dapat disimpulkan :

1. Secara bersama-sama atau simultan terdapat pengaruh yang positif dan signifikan antara kepemimpinan dan lingkungan kerja fisik terhadap motivasi kerja karyawan CV. Sedulur Palembang. Hal ini berarti apabila ada peningkatan dalam kepemimpinan dan lingkungan kerja fisik maka motivasi kerja karyawan juga akan meningkat.

2. Secara parsial terdapat pengaruh positif dan signifikan antara kepemimpinan terhadap motivasi kerja karyawan CV. Sedulur Palembang, artinya apabila ada peningkatan dalam kepemimpinan maka semangat 
kerja karyawan juga akan meningkat.

3. Secara parsial juga terdapat pengaruh positif dan signifikan antara lingkungan kerja fisik terhadap motivasi kerja karyawan CV. Sedulur Palembang, hal ini mengandung makna apabila ada peningkatan dalam lingkungan kerja fisik maka semangat kerja karyawan juga akan meningkat.

2. Saran.

1. Motivasi kerja berkaitan erat dengan kepemimpinan dan lingkungan kerja fisik untuk mencapai tujuan organisasi yang efektif dan efisien. Untuk itu diharapkan Pimpinan CV. Sedulur Palembang harus terus memberikan motivasi kepada karyawannya seperti memberikan penghargaan berupa promosi jabatan.

2. Kepemimpinan dalam sebuah perusahaan haruslah selalu melakukan motivasi dan memperhatikan kinerja karyawannya, salah satunya dengan cara memberikan penghargaan kepada pegawai yang berprestasi, seperti reward atau bonus-bonus.

3. Pimpinan perusahaan harus memperhatikan lingkungan kerja fisik dengan baik untuk mendukung pekerjaan yang dilaksanakan oleh karyawan, sehingga dapat mendorong motivasi kerja karyawan.

\section{DAFTAR PUSTAKA}

Alex. S. Nitisemeto, (2002).
Manajemen Personalia.
Cetakan kesembilan, edisi
ketiga, Penerbit Ghali
Indonesia, Jakarta.

Haryono, Siswoyo. (2007). Metode penelitian bisnis. Palembang: MMUTP.

penelitian (2007). Statistika
$\begin{aligned} & \text { dengan program Sanajemen } \\ & \text { Edisi pertama, Jakarta. }\end{aligned}$

Husen Umar, (2006). Riset Sumber Daya Manusia Dalam Organisasi, Edisi Revisi \& Perluasan, Penerbit PT .Gramedia Pustaka Umar.

H.B Siswanto. (2006). Pengantar Manajemen. Penerbit Bumi Aksara.

I Gusti Nugraha Gorda, (2004 \& 2006). Manajemen Sumber Daya Manusia. Penerbit Astrabrata Bali, Denpasar.

Kenneth N. Wexley dan Gary A.Yuki, (2003). Prilaku Organisasi dan Psikologi Personalia, Penerbit Reneka Cipta, Jakarta.

Mifta Thoha, (2003) Kepemimpinan Dalam Manajemen Seatu Pendekatan Prilaku. Cetakan kesembilan, Penerbit PT. Raja Grafindo Persada, Jakarta.

Rivai, Veithzal. (2004). Kepemimpinan dan Prilaku Organisasi. Edisi 2, Penerbit PT. Raja Grafindo Persada, Jakarta.

Sondang, P. Siagian, (2004). ). Manajemen Sumber Daya Manusia. Penerbit Bumi Aksara, Jakarta.

Sugiono, (2002). Metode Penelitan Bisnis (Pendekatan kuantitatif. Kualitatif dan $R \& D)$. Penerbit Alfabeta, Bandung.

\begin{tabular}{|c|c|}
\hline & $\begin{array}{l}\text { Untuk Penelitaan. } \\
\text { kedelapa, Penerbit } \\
\text { Bandung. }\end{array}$ \\
\hline Supardi & $\begin{array}{l}\text { dan Syaiful Anwar, } \\
\text { Dasar-dasar }\end{array}$ \\
\hline
\end{tabular}


Organisasi. Penerbit UII Press, Yogyakarta.

Sunyoto, Danang. (2007). Analisis

Regresi dan Korelasi

Bivariat. Penelitian Amara

Books, Yogyakarta. 